\title{
Insight into the biogenesis of tax nuclear speckles using comparative interactome analysis
}

\author{
Hampus Engstrom, David J Archer, Sucharita Dutta, John O Semmes ${ }^{*}$ \\ From 17th International Conference on Human Retroviruses: HTLV and Related Viruses \\ Trois Ilets, Martinique. 18-21 June 2015
}

HTLV-1 Tax protein displays pleotropic activities that regulate many aspects of virus biology, host-pathogen interaction and disease development. Tax performs these various functions via protein-protein interactions and sub cellular compartmentalization appears to regulate which activities are engaged. We previously identified a novel nuclear body, Tax Speckled Structures (TSS), the biogenesis of which supports the sequestration of cellular DNA Damage Response factors by Tax to chromatin. To identify cellular proteins that drive localization of Tax to chromatin "speckles", we conducted a Comparative Interactome Analysis of Tax and a Tax mutant missing the TSS localization signal (TaxTSLS). Tandem affinity tagged Tax and mutant proteins were expressed in eukaryotic cells. Cytoplasmic, nuclear and chromatin fractions were generated and protein interactomes isolated by affinity purification. Those proteins that preferentially bound full-length Tax over TaxTSLS were defined as the TSLS-specific interactome. Quantitative Ultra-high resolution tandem mass spectrometry was employed to establish the most comprehensive map of Tax-interacting proteins to date. We employed bioinformatics approaches to compare Tax interactomes and identify the functional pathways and interaction networks unique to proteins that bound the TSLS-defined region. The top functional networks for proteins that bound to the TSLS were involved in chromosomal alignment, congression, segregation, remodeling and modification. The overwhelming majority were known components of four chromatin functional super-complexes condensin I, kinesin, SWI/SNF and NURF. We also examined the protein interactions that were shared by full length and mutant Tax. These included significant interaction with DNA damage, cell cycle check point, NFkB signaling, and

\footnotetext{
* Correspondence: Semmesoj@evms.edu

The Leroy T Canoles Jr. Cancer Research Center, Eastern Virginia Medical School, Norfolk, Virginia, USA
}

(c) 2015 Engstrom et al. This is an Open Access article distributed under the terms of the Creative Commons Attribution License (http:// creativecommons.org/licenses/by/4.0), which permits unrestricted use, distribution, and reproduction in any medium, provided the original work is properly cited. The Creative Commons Public Domain Dedication waiver (http://creativecommons.org/publicdomain/ zero/1.0/) applies to the data made available in this article, unless otherwise stated. protein sorting pathways. A comparative analysis between the sub cellular fractions revealed that DNA damage and checkpoint signaling interactions were enriched in the nucleus/chromatin. These results demonstrate that Tax initiates TSS through binding of chromatin complexes and bridges the recruitment of DNA damage response and checkpoint signaling proteins.

Published: 28 August 2015

doi:10.1186/1742-4690-12-S1-O35

Cite this article as: Engstrom et al:: Insight into the biogenesis of tax nuclear speckles using comparative interactome analysis. Retrovirology 2015 12(Suppl 1):O35.

Submit your next manuscript to BioMed Central and take full advantage of:

- Convenient online submission

- Thorough peer review

- No space constraints or color figure charges

- Immediate publication on acceptance

- Inclusion in PubMed, CAS, Scopus and Google Scholar

- Research which is freely available for redistribution 